\title{
The Mediating Role of Organizational Justice in Linking Human Resource Practices to Employee Outcomes: Evidence from Indian Banks
}

\author{
Shalini Sahni and Chandranshu Sinha **
}

\begin{abstract}
The study represents a pioneering and seminal attempt to understand the implications of human resource practices on employee outcomes in the Indian banking sector from an organizational justice perspective. The study aims to examine the mediating influence of organizational justice perception between HR Practices and employee outcomes of job satisfaction and stress. The study expands by examining three different dimensions of organizational justice namely, distributive justice, procedural justice, and interactional justice. Data was collected using stratified sampling from 328 respondents from Indian public and private banks in Delhi. The study tests the conceptual framework using exploratory factor analysis, confirmatory factor analysis and path analysis for mediation effect using Hayes approach of boot strap method. Using cross-level analysis, the relative influence of interactional justice was found to be largest for job satisfaction in private banks. The study contributes to the existing debate that exist around "how" employee perception of human resource practices leads to employee outcomes. This research will sensitize human resource practitioners working in Indian banks on how to implement human resource practices as an intervention to bring positive employee outcomes.
\end{abstract}

Keywords: Organizational Justice, Human Resource Practices, Path Analysis, Mediation, Job Satisfaction, Stress, Banks

\section{INTRODUCTION}

Employees of an organization serve as a vital source of competitive advantage and are considered as one of the most integral part of any organization (Huselid, 1995; MacDuffie, 1995) for achieving organizational growth and performance (Becker \& Gerhart, 1996; Therefore, over a period of time, as employees integrate in the organizations, they perceive and continuously evaluate various human resource practices (Kuvaas, 2008). In a study by Katou, Budhwar, and Patel, (2014), they suggested that human resource management practices are considered to be playing a significant role in influencing the factors of organizational and individual performance. Employee attribution of "how" employees selectively process the information about human resource practices (Mischel \& Shoda, 1995), and accordingly it contributes to positive and negative employee outcomes (CoyleShapiro \& Conway, 2004).

Literature indicates that so far not much has been known about how human resource practices (HRP) lead to

\footnotetext{
Assistant Professor, Banarsidas Chandiwala Institute of Professional Studies, Dwarka, New Delhi and Research Scholar, Amity University, Noida.E-mail: shalinisah75@gmail.com (Corresponding Author)

** Professor, Amity Business School, Amity University, Noida. E mail id: chandranshu.sinha@gmail.com
} 
employee outcomes (Harley et al., 2007), therefore the cause-and-effect relationship established between the two is highly complex (Jiang et al., 2012). Tracing its genesis demands analyzing the causal effect of human resource practices on employee outcomes from multiple perspectives. This includes exploring and understanding the perspective of Human resource managers, and other employees as recipients of Human resource Practices. This focus is required as wide range of literature available has not been given any due attention to the employees who have been at the receiving end (Legge, 1995). A better understanding of "how" and "why" an employee perceives a situation is a prerequisite for understanding the potential linkage between human resource practices and employee outcomes (Macky \& Boxall, 2007). This would also help in designing and communicating human resource practices for the well-being of the employees and would eventually help in understanding how employee outcomes are shaped.

Studies mentioned above have drawn attention towards lack of theory development and the need for explaining those variables that selectively influence the processing of information about human resource practices (Mischel \& Shoda, 1995) that influence employee outcomes. This study took a process approach to explaining the "how" human resource practices are related to improved employee outcomes. Number of studies have provided evidence that human resource are related to employee outcomes (Wood \& de Menezes, 2011), yet they have been critiqued for not providing concrete empirical evidence of specifying the mediating processes by which human resource practices lead to employee outcomes (Delery,1998; Guest, 2017). In fact, there is ample evidence available that raises concern for not providing a precise mechanism through which human resource practices affect employee outcomes (Dyer \& Reeves, 1995) and calls for attention (Takeuchi, Chen, \& Lepak, 2009). In the past, some of the studies have considered mediating variables between the two like interactional justice (Kuvaas, 2008), job satisfaction ( Kundu \& Gahlawat, 2015), employee human resource attributions and employee well-being (Khoreva \&Wechtler,2018) but those have not been able to provide an in-depth understanding of any intermediate mechanism between the two (Jiang et al., 2012). Farndale et al. (2011) also added that there is a huge gap present between the understanding of "how" employee perception of human resource practices leads to employee outcomes. In brief, a huge gap exists which requires further investigation of "how" human resource practices are perceived by the employees and its relationship with employee outcomes in organizational settings (Sanders \& Yang, 2016). Drawing upon the above arguments, the study would contribute in deciphering this causal linkage and further proposes to explore the perception of organizational justice by the employees as one of the potential mediators between human resource practices and employee outcomes, specifically in the Indian banking industry. In other words, the study is aimed to find the connections between human resource practices and employee outcomes by using the construct of organizational justice as a mediator The study understands this perspective from the lens of Organizational behavior (OB) and is based on the assumption that people perceive differently (Ichheiser, 1949; Hayibor's, 2017). This implies that employees attach different meanings to these practices as these perceptions can be built toward distribution of resources (such as salary, bonus, incentives, and awards), organizational processes (such as performance appraisal, organizational change etc.) (Kaneshiro, 2008). This implies that employees will have different outcomes based on their individual experiences of justice perception, which vary from one individual to another (Hayibor, 2017). The difference in experience and perception of fairness or unfairness of decisions and of processes and interactions is recognized as organizational justice (Colquitt \& Greenberg, 2003; Asadullah et al., 2017), suggests the role of organizational justice in determining employee outcomes through human resource practices.

The three dimensions of organizational justice, namely, distributive justice, procedural justice, and interactional justice have been considered to understand the linkage between human resource practices and employee outcomes. The study would be conducted in Indian banking sector which is considered as the life line of economy (Sharma \& Sindhu, 2016). The recent developments in the Indian banking sector like, merger of ten big state- 
owned banks to form four big banks in 2019, thereby reducing the state-owned public banks to 12 from 27 in $2017^{1}$, merger of the State Bank of India (SBI) in 2017, has posed many challenges for the individuals as employees experience stress of uncertainty, insecurity, compensation changes, and changes in reporting structure (Schweiger \& Ivancevich, 1985). In this situation, literature suggests that banks require more committed workforce (Nidhi \& Kumari, 2019) that organizational justice has a potential to explain a wide range of behaviors that are responsible for low performance of an employee (Fernandes \& Awamleh, 2006) and highlights organizational justice as a crucial element for organizations to function effectively (Greenberg, 1993). Thus, this study is an attempt to help the Indian banking industry in overcoming such crises by informing banking organizations of different employee outcomes based on fairness perception of HR practices and raises a research question(RQ):

How employees selectively process the information about human resource practice.

\section{ORGANIZATIONAL JUSTICE AND EMPLOYEE OUTCOMES}

Literature has classified organizational justice into three main categories: Distributive Justice (fairness of distribution), Procedural Justice (fairness of processes), and Interactional Justice (interpersonal and informational justice). The first dimension, distributive justice has its focus on a social comparison based on rewards and is based on Adam's Equity Theory. Adams (1965) argues that employees experience a greater degree of satisfaction when the ratio of their inputs to outcomes is same as the ratio of inputs to outcomes of others. If employees perceive injustice or inequity while comparing their outputs with others, they tend to develop negative feelings and experience distributive injustice (Folger \& Cropanzano, 1998). Thus, Adams' Equity Theory employs a concept of distributive Justice.

The second constituent of organizational justice is known as procedural justice and is defined as the process by which an employee perceives the policies and procedures used to distribute or allocate the outcomes at the workplace (Leventhal, 1980). Leventhal (1980) suggested that different rules are deployed in different situations and the type of situation determines the nature of the rules applied. This signifies that one procedural rule may not work as effectively as another at a different time.

Bies and Moag (1986) suggested that process of distribution of outcomes in an organization consists of three events: a) a procedure b) the communication between allocator and recipient c) the result or the outcome itself. These events are subsequential in nature and create an interaction phase where people evaluate social fairness, when a decision-maker treats an individual with dignity and respect, interpersonal Justice is perceived (Bies \& Moag, 1986). When a decision-maker provides complete information and justification, informational Justice is most likely to be perceived (Bies, 2001). Both interpersonal justice and informational justice are the two important parameters of measuring interactional Justice and is responsible for measuring employee outcomes at an individual level (Colquitt et al., 2001).

Studies suggest that the construct of organizational justice is similar to HR practices and is a strong predictor of employee's cognitive and behavioral outcomes (Folger \& Konovsky, 1989), but most of the researches on organizational justice fails to examine the employee outcomes through the three dimensions of organizational

This information has been retrieved from https:/economictimes.indiatimes.com/news/economy/policy/big-bank-mergersgovernment-turns-ten-psbs-into-four/articleshow/70918585.cms?from=mdr, accessed on 23 November, 2019 
justice separately in the banking sector. Considering that employee outcomes are important in driving higher operational and financial performance of the organizations, the nature of employee outcomes should be understood. (Collins, Ericksen, \& Allen, 2005). Furthermore, this study will add to the existing literature of organizational justice theory, as justice studies in India have been studied from the angle of social justice particularly in the context of cultural diversity, social cognition, mental health, and so on (Krishnan, 2015; Karunakaran, 2018). The current study is designed to add on to the body of knowledge vis-s-vis organizational justice studies in organizational settings, something, which has not been attempted (Huong, Zheng, \& Fujimoto, 2016). Therefore, it is appropriate to ask, where the Indian Banking sector stands with respect to human resource system and whether the banks follow the evidence-based approach of human resource Practices to improve employee outcomes. This research will use organizational justice as the main framework and "lens" through which the effectiveness of human resource practices on employee outcomes can be examined.

\section{EMPLOYEE OUTCOMES IN RESPONSE TO HUMAN RESOURCE PRACTICES}

Guest (1987) in an attempt to define HRM, identified two perspectives: soft HRM and hard HRM. Hard approach (Fombrun, Tichy, \& Devanna, 1984) to HRM is unmindful of the needs and desires of the employees in an organization, while soft HRM (Beer, Spector, Lawrence, Quinn-Mills \& Walton, 1984) is sensitive to the needs of the employees and focuses on the employee outcomes. There has been a conflict between the two approaches, and the scholars show more inclination towards soft HRM (Noon, 1992). In this backdrop, the current study uses soft HRM approach, which has recently gained attention in both academia and the corporate world (Gould-Williams, 2007).

In the Indian context, where HRM function is still evolving in terms of HR practices, and organizations are uncertain due to diverse workforce, the current study uses soft HRM approach, which is sensitive to the needs of the employees and focuses on the employee outcomes. The significance of some employee outcomes in different particular business sectors is still contested. The two most dominant employee outcomes in Indian banking industry mentioned in the literature are job satisfaction and stress. These employee outcomes are similar to other empirical studies that have tested an association of HR practices with stress (Gould-Williams \& Mohamed, 2010) and job satisfaction (Latorre et al., 2016) but are critical to the organization and employee performance (Eatough et al., 2011).

Job satisfaction is the major area of concern in Asian countries (Noypayak \& Speece, 1998) due to conspicuous diversity in race, culture, and values. Employee outcome in the form of job satisfaction has been the subject of discussion over the past few decades due to its significance among employees and employers. It refers to an emotional state of mind (Judge \& Klinger, 2008) and the attitude that people have towards their work (Armstrong, 2014).

Stress at work is defined as "a harmful reaction that people have to undue pressures and demands placed on them at work." It is a condition when an individual realizes that the demands at the workplace are much higher than they can manage. One of the main reasons for the apparent increase in work stress is global economic crisis that had hit the world in 2008 (Conway et al., 2016). Since then, there has been sweeping transformation of processes, heavy workload, job cuts, job insecurities, and new conditions of employment (Truss,2013). Changes of this magnitude have affected employees in private and public sector organizations alike. But it is to be noted that the impact of changes is slightly more on the employees working in public sector organizations since they have defined public sector jobs as ideal and employee-friendly owing to countless benefits and incentives that they bestow on their employees (Truss, 2013). Research to date on stress has been conducted at an organizational level (Denis, Ferlie \& Van Gestel, 2013) with less attention paid to employees and how they respond to new HR practices formed due to 
such environmental changes (Colley, McCourt \& Waterhouse, 2012). This in turn sends mixed signals to employees, and employees, too, reciprocate with unexpected behavior such as withdrawal, poor performance, stress, low job satisfaction, and so on. This forms the basis of the research to explore some of the pressures within HRM literature which has been hitherto neglected at an employee level but continues to be an important area of research (Ehrnrooth \& Bjorkman, 2012).

\section{Hypothesis Development}

In organizations, HR practices exist at the macro level-organizational level-but organizational justice perceptions of employees and employee outcomes prevail at the individual level. HR practices such as training, recruitment, compensation, job security etc. are the means through which information is shared or acquired (Huselid, 1995).Employees who are at the receiving end perceive and examine these HR practices through their experiences, which are majorly driven by the requirement of fair treatment (Bowen, Gilliland, \& Folger, 1999). These justice perceptions are automatic but a systematic process where employees evaluate every information available to them and form an opinion or a judgment (Cropanzano et al., 2001). This prompts employees to retaliate through behavioral outcomes. The retaliation is due to the breach of the psychological contract that exists between employer and an employee and Rousseau (1985) claims that breach is related to perceptions of unfairness and inequity. Sparrow (1998) emphasized that it is the responsibility of HRM function to establish strong psychological contract between an employer and the employees. Therefore, the employee is usually uncertain about his or her relationship with the employer and is dependent on cognitive thinking or their experience of fair treatment to guide subsequent employee outcomes. Therefore, the present study proposes to check fairness perception known as organizational justice (Greenberg, 1993) as a psychological mechanism, which acts as a mediator between HR practices and contributes to different employee outcomes.

Previous researches have consistently established that justice perceptions at workplace predicts employee attitude and behaviors (Gilliland \& Chan, 2001). Within HRM and behavioral science literature, there is a growing awareness among researchers to consider both desirable and undesirable responses of employees, thus the employee outcomes in the form of stress and job satisfaction are examined through the lens of all three dimensions of organizational justice as a mediator, which is represented in a conceptual framework as shown in Figure 6.1 and hypothesized below.

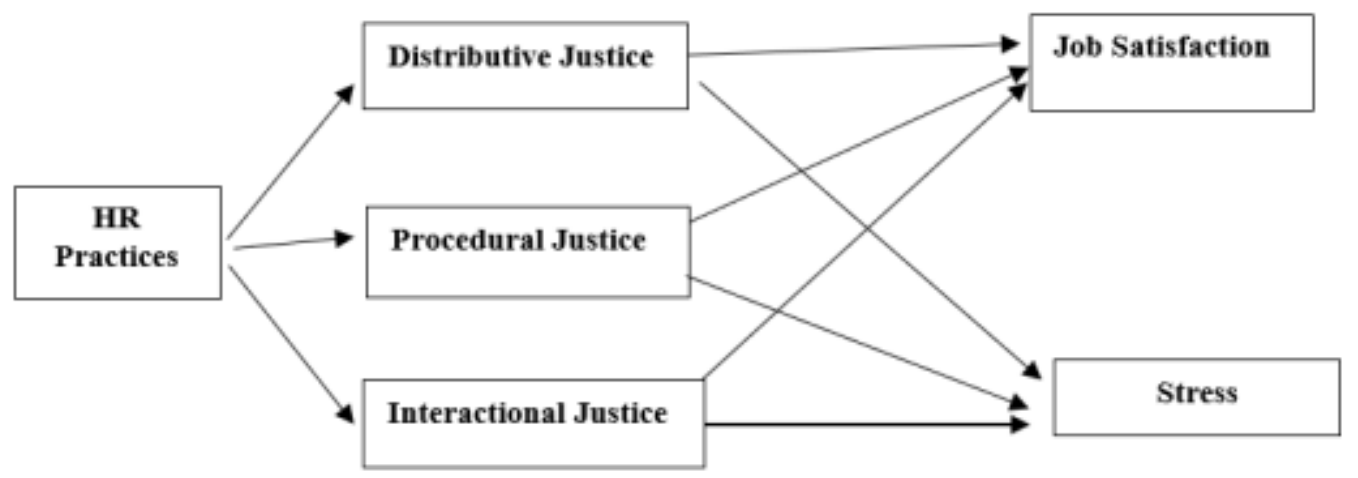

Figure 1: Mediating Effect of Organizational Justice 
- Distributive justice will mediate the relationship between HR practices and stress in private-sector banks (H1a)/ public-sector banks (H1b);

- Distributive justice will mediate the relationship between HR practices and job satisfaction in private-sector banks (H2a) / public-sector banks (H2b).

- Procedural justice will mediate the relationship between HR practices job satisfaction in private-sector banks (H3a)/public-sector banks (H3b);

- Procedural justice will mediate the relationship between HR practices and stress in private-sector banks (H4a)/public-sector banks (H4b);

- Interactional justice will mediate the relationship between HR practices and job satisfaction in private-sector banks (H5a)/public-sector banks (H5b);

- Interactional justice will mediate the relationship between HR practices and stress in private-sector banks (H6a)/public -sector banks (H6b);

\section{METHODS}

\section{Sample and Procedures}

Data was collected through stratified sampling technique and the information was obtained from full-time employees of private and public sector banks in New-Delhi from nine strata's: North-west, North-east, North, East, South-east, South, South-west, West, and Central Delhi in accordance with Registrar of Cooperative Societies.

A total of 1200 questionnaires were distributed among the bank employees in nine different strata's and only 328 questionnaires were found to be in the usable form. In other words, the sample size for testing the hypothesis was 328 , where 171 responses were obtained from private-sector banks and 158 responses were obtained from publicsector banks.

This study adopts path analysis as a part of structural equation modelling (SEM) for data analysis of the data collected. This study followed Preacher and Hayes (2004) approach of mediation analysis and also confirmed the indirect effect through the method of bootstrapping.

\section{Measures}

The questionnaire was divided into three sections; HR Practices, Organizational Justice (Distributive justice, Procedural justice and Interactional justice) and Employee outcomes (job satisfaction, stress and turnover intention) which consisted of 40 items. All the items in the questionnaire were measured on a five-point Likert scale, where 1 was considered as "Strongly Disagree" and 5 as "Strongly Agree." Human Resource Practices had nine practices were adapted from Guthrie (2001), relating to viz. employee sourcing, training and development, compensation, performance appraisal, employee involvement, work-life balance, job security, grievance 
handling and job rotation. Six item scale of Distributive Justice was adapted from Colquitt (2001) and checked for measuring the perceptions of distributive justice toward the bunch of HR practices that exist in the banks. Procedural Justice was adapted from McFarlin and Sweeney (1992) and six items were to measure the construct of proceduaral justice in relation to the study, which included items related to training, layoffs, grievances, appraisals and career growth for the current study. Eight item scale of Interactional Justice was adapted from Bies and Moag (1986) to measure the construct of interactional justice in relation to the study. In order to measure the construct of interpersonal justice, the items related to treatment of employees and items related to information and feedback of appraisal was used. A seven-item scale of Job Satisfaction was adapted from Mathieu and Farr(1991) to measure the items relating to the satisfaction level with superiors, competency of the supervisor, feeling of accomplishment, recognition of work, and satisfaction with the company policies. A four-item scale by Shain (1999) of Stress was adapted to measure the construct of control, effort representing stressors and reward representing satisfaction.

\section{Analysis}

The study used Exploratory Factor Analysis (EFA) with maximum likelihood estimation using varimax rotation to estimate the factor structure of our measurement model. Bartlett's test of sphericity and KMO value (0.776) (degree of freedom is 780, significance is 0.000 ), confirmed that data was fit for factor analysis. Factor loadings less than 0.40 were excluded which led to the extraction of six components with Eigenvalue greater than 1 and each factor having multiple items. In EFA, total two items were dropped due to poor loading, in which one item was dropped from interactional justice and one more item was dropped from HR Practices. The factors extracted accounted for $74.626 \%$ variance. Overall reliability of the instrument was measured through Cronbach alpha coefficient whose value was 0.955 for 40 items.

Further, the measurement model is tested for validity and reliability of the constructs. The adequacy of the model fit is determined by several goodness-of-fit statistics, including chi-square, root mean square error of approximation (RMSEA), standardized root mean square residual (RMR), goodness of-fit index (GFI), and comparative fit index (CFI). In order to assess model fits, conventional cut-off recommended by Kline (2005) are followed to check the goodness of fit.

\section{Results}

The CFA results achieved the goodness of fit as the value of CMINI/df achieved is 1.781 and RMSEA was 0.049, RFI is 0.8320 , IFI is 0.925 , and CFI is 0.924 . To test the hypothesized model, reliability of the construct is calculated using composite reliability and average variance extracted (AVE). Composite reliability is established if its value is equal to or greater than 0.70 (Hair et al., 2010). It is given that AVE of 0.50 or greater proposes adequate converge (Hair et al., 2010). Further, both convergent and discriminant validity was established to check construct validity with the help of average variance extracted (AVE), average shared variance (ASV), and maximum shared variance (MSV). As a rule, discriminant validity is established if a latent variable's AVE is larger than the common variances or MSV (squared correlations) of the latent variable (Fornell \& Larcker, 1981, p. 46). Both construct validity and discriminant validity is established using AMOS and statistical package and the results of the same are shown in table 1 below: 
Table 1: Construct and Discriminant Validity

\begin{tabular}{|l|l|l|l|l|l|l|l|l|l|l|}
\hline & CR & AVE & MSV & MaxR(H) & sat & DJA & PJA & IJA & stress & HR \\
\hline Sat & 0.880 & 0.511 & 0.354 & 0.881 & $\mathbf{0 . 7 1 5}$ & & & & & \\
\hline DJA & 0.876 & 0.541 & 0.258 & 0.937 & 0.508 & $\mathbf{0 . 7 3 5}$ & & & & \\
\hline PJA & 0.873 & 0.535 & 0.195 & 0.956 & 0.358 & 0.442 & $\mathbf{0 . 7 3 1}$ & & & \\
\hline IJA & 0.917 & 0.581 & 0.354 & 0.971 & 0.595 & 0.371 & 0.347 & $\mathbf{0 . 7 6 2}$ & & \\
\hline stress & 0.876 & 0.640 & 0.245 & 0.976 & 0.495 & 0.274 & 0.265 & 0.285 & $\mathbf{0 . 8 0 0}$ & \\
\hline HR & 0.930 & 0.596 & 0.174 & 0.982 & 0.417 & 0.260 & 0.215 & 0.351 & 0.309 & $\mathbf{0 . 7 7 2}$ \\
\hline
\end{tabular}

The study aims to analyze the mediating effect of organizational justice present between the causal chain of HR Practices and employee outcomes. The current study draws upon the Preacher and Hayes (2004) approach that suggests bootstrapping for testing indirect effects as it does not make any assumptions about the shape of sampling distributions.

The next section tests the hypothesized (H1to H6) conceptual framework presented in figure 1 and tests the various mediating paths through path analysis (a special case of SEM) in private and public sector banks. The framework in figure 1 presents HR practices (HRP) perception as an independent variable, organizational justice dimensions (distributive justice, procedural justice, interactional justice) as mediators and describes two forms of employee outcomes (job satisfaction, stress) as dependent variable.

\section{Mediating Effects of Distributive Justice in Indian Private and Public-Sector Banks}

H1 Distributive justice perception mediates between human resource practices (HRP) and stress (H 1 a) in private and Public-sector banks(H1b).

Mediation analysis in private banks indicated that HRP (IV) significantly predicts distributive justice (DV) $(\beta=$ $0.25, p=0.001)$, distributive justice also significantly predicts stress $(\beta=0.22, p=0.023)$, and HR practices significantly predicts stress $(\beta=0.25, p=0.023)$. The direct effect $\left(r^{2}=0.09\right)$ of HR practices on stress gets increased to 0.14 (indirect) when distributive justice is introduced as a mediator. Further, bootstrapping procedure indicated that indirect effect $(\mathrm{E}=0.047, p=0.014)$ and the direct effect $(\mathrm{E}=0.219, p=0.004)$ of distributive justice between HR Practices and stress is significant thereby confirming partial mediation of distributive justice between HRP and stress in private-sector banks. Hence hypothesis 1(a) is accepted.

Further, in public-sector banks, results indicated that all paths are significant and further, bootstrapping procedure was performed at $95 \%$ confidence level, the direct effect $\left(r^{2}=0.09\right)$ of HR practices on stress increased to 0.13 (indirect) when distributive justice is introduced as a mediator. Simultaneously, bootstrap results for direct effect $(\mathrm{E}=0.287, p=0.002)$ and indirect effect $(\mathrm{E}=0.064, p=0.011)$ also suggest the significance as shown in table 2, thereby confirming partial mediation of distributive justice between HRP and stress in public sector banks. Hence, hypothesis 1(b) is accepted. 
Table 2: Distributive Justice as a Mediator between HRP and Stress in Private and Public-Sector Banks

\begin{tabular}{|c|c|c|c|c|c|c|}
\hline & Private Banks & & & Public Banks & & Remarks \\
\hline Effect & $\begin{array}{c}\text { Standardized } \\
\text { Beta }\end{array}$ & $P$ value & Remarks & $\begin{array}{c}\text { Standardized } \\
\text { Beta }\end{array}$ & P value & \\
\hline Total Effect & .266. & 001 & \multirow{3}{*}{$\begin{array}{l}\text { Partial } \\
\text { Mediation } \\
\text { exists }\end{array}$} & .351 & .001 & \multirow{3}{*}{$\begin{array}{l}\text { Partial } \\
\text { Mediation } \\
\text { exists }\end{array}$} \\
\hline Indirect Effect & .047 & .014 & & .064 & .011 & \\
\hline Direct Effect & .219 & .004 & & .287 & .002 & \\
\hline
\end{tabular}

H2 Distributive justice perception mediates between HR practices and Job satisfaction (H2 a) in private and Public-sector banks (H2 b).

Mediation analysis of distributive justice between HR practices and job satisfaction in private-sector banks indicated that HRP (IV) significantly predicts distributive justice (DV) $(\beta=0.25, p=0.006)$, distributive justice also significantly predicts job satisfaction $(\beta=0.40, p=0.023)$ and HRP significantly predicts job satisfaction $(\beta=$ $0.39, p=0.023)$. Further, bootstrapping procedure was performed at $95 \%$ confidence and the results indicated that indirect effect of HRP on job satisfaction is significant $(\mathrm{E}=0.049, p=0.003)$, showing the effect of mediation of distributive justice. The direct effect $\left(r^{2}=0.14\right)$ of $\mathrm{HR}$ practices on job satisfaction gets increased to 0.39 (indirect) when distributive justice is introduced as a mediator. This indicates the distributive justice influences job satisfaction by a significant amount. Simultaneously, bootstrap results for indirect effect shows significant $p$ value $(\mathrm{E}=0.049, p=0.003)$, thereby confirming mediation. Direct effect of perception of HR practices on job satisfaction shows significance $(\mathrm{E}=0.191, p=.001)$, hence solidifying partial mediation of distributive justice in private-sector banks as shown in Table 3. Hence, hypothesis 2(a) is accepted.

Further in public sector banks, results of mediation of distributive justice between HR practices and job satisfaction, indicated that HRP (IV) significantly predicts distributive justice (DV) $(\beta=0.28, p=0.001)$, distributive justice also significantly predicts job satisfaction $(\beta=0.44, p=0.023)$, and HRP practices significantly predicts job satisfaction $(\beta=.25, p=0.023)$. Further, bootstrapping results indicated that indirect effects of HR practices on job satisfaction is $(\mathrm{E}=0.064, p=0.011)$ significant, showing the indispensable impact of mediation of distributive justice. The direct effect $\left(r^{2}=0.14\right)$ of HR practices on job satisfaction increased to 0.32 when distributive justice is introduced as a mediator. Simultaneously, bootstrap results for direct effect $(\mathrm{E}=$ $0.255, p=0.003)$ and indirect effects $(\mathrm{E}=0.129, p=0.000)$ also indicates the significance, thereby confirming partial mediation of distributive justice between HRP and job satisfaction in public-sector banks as shown in Table 3. Hence, hypothesis 2 (b) is accepted.

Table 3: Distributive Justice as a Mediator between HRP and Job Satisfaction in Private and publicSector Banks

\begin{tabular}{lcclllll}
\hline \multicolumn{1}{c}{ Effect } & Private Banks & $\begin{array}{c}\text { Standardized } \\
\text { Beta }\end{array}$ & P value & Remarks & $\begin{array}{c}\text { Standardized } \\
\text { Beta }\end{array}$ & P value & \\
\hline Total Effect & .239 & .001 & Partial & .383 & .001 & Partial \\
Indirect Effect & .049 & .003 & Mediation & .129 & .000 & Mediation \\
Direct Effect & .191 & .001 & exists & .255 & .003 & exists \\
\hline
\end{tabular}




\section{Procedural Justice as a Mediator in Private and Public-Sector Banks}

H3 Procedural justice perception mediates between HR practices and Job satisfaction in private (H3 a)and publicsector banks (H3b).

To test mediation of procedural justice between HRP and job satisfaction, results indicated that HR P (IV) significantly predicts procedural justice (DV) $(\beta=0.19, p=0.000)$, procedural justice also significantly predicts job satisfaction $(\beta=0.26, p=0.000)$, and HRP significantly predicts job satisfaction $(\beta=0.44, p=0.000)$ as shown in Figure 8.8. Further, bootstrapping results indicated that both direct effect of $\mathrm{HRP}$ on job satisfaction $(\mathrm{E}=0.312$, $p=0.001)$ and indirect $(\mathrm{E}=0.034, p=0.021)$ are significant, showing the effect of mediation of procedural justice. The direct effect $\left(r^{2}=0.14\right)$ of HRP on job satisfaction gets increased to 0.31 with the introduction of procedural justice as a mediator. This indicates the importance of distributive justice as a mediator between the shown path. Simultaneously, bootstrap results for indirect effect $(\mathrm{E}=0.034, p=0.021)$ and direct effect $(\mathrm{E}=0.312, p=0.001)$ also indicates the significance, thereby confirming partial mediation of procedural justice between HRP and job satisfaction in private-sector banks as shown in Table 4. Hence, hypothesis 3(a) is accepted.

In an effort to test mediation of procedural justice between HR practices and job satisfaction, results in Figure 8.9 indicate that HRP (IV) significantly predicts procedural justice (DV) $(\beta=0.25, p=0.005)$, procedural justice also significantly predicts job satisfaction $(\beta=0.30, p=0.000)$, and HR practices significantly predict job satisfaction $(\beta=0.29, p=0.000)$. Further, bootstrapping procedure at $95 \%$ confidence level indicated that an indirect effect of HR practices on job satisfaction is $(\mathrm{E}=0.078, p=0.003)$ significant, showing the effect of mediation of procedural justice. The direct effect $\left(r^{2}=0.14\right)$ of HR practices on job satisfaction rose to 0.22 when procedural justice is introduced as a mediator. Simultaneously, bootstrap results as shown in Table 4 for direct effect $(\mathrm{E}=0.071, p=$ $0.003)$ and indirect effect $(\mathrm{E}=0.078, p=0.003)$ also indicates the significance, thereby confirming partial mediation of procedural justice between HRP and job satisfaction in public-sector banks. Hence hypothesis 3 (b) is accepted.

Table 4: Procedural Justice as a Mediator between HRP and Job Satisfaction in Private and publicSector Banks

\begin{tabular}{cccllll}
\hline & Private Banks & & & Public Banks & Remarks \\
\hline \multicolumn{1}{c}{ Effect } & $\begin{array}{c}\text { Standardized } \\
\text { Beta }\end{array}$ & P value & Remarks & $\begin{array}{c}\text { Standardized } \\
\text { Beta }\end{array}$ & P value & \\
\hline Total Effect & 0.346 & 0.001 & Partial & .384 & .001 & Partial \\
Indirect Effect & 0.034 & 0.021 & Mediation & .078 & .003 & Mediation \\
Direct Effect & 0.312 & 0.001 & exists & .071 & .003 & exists \\
\hline
\end{tabular}

H4 Procedural justice perception mediates between HR practices and stress in private $(\mathrm{H} 4 \mathrm{a})$ and public sector banks(H4b).

The result indicates that HRP (IV) significantly predicts procedural justice (DV) $(\beta=0.19, p=0.035)$, procedural justice does not predict stress significantly $(\beta=0.16, p=0.079)$, and HRP significantly predicts stress $(\beta=0.28, p$ $=0.002)$. The direct effect $\left(r^{2}=0.09\right)$ of HR practices on stress increases to 0.12 when procedural justice is introduced as a mediator. Though the increase is marginal but procedural justice does not mediate the path. Further, bootstrapping results showed that indirect effect $(\mathrm{E}=0.025, p=0.064)$ is not significant but direct effect is 
significant $(\mathrm{E}=0.240, p=0.001)$, thereby confirming no mediation at all (Table 5). Hence, hypothesis $4(\mathrm{a})$ is rejected.

Results in public-sector banks indicate that HRP (IV) significantly predicts procedural justice (DV) $(\beta=0.25, p=$ $0.005)$, procedural justice also significantly predicts stress $(\beta=0.26, p=0.004)$, and HR practices significantly predict stress $(\beta=0.24, p=0.004)$. The direct effect $\left(r^{2}=0.09\right)$ of HR practices on stress increased to 0.16 (indirect) with the introduction of procedural justice as a mediator. Further, bootstrapping results showed the difference between the direct and the indirect effect; direct effect is much greater $(\mathrm{E}=0.350, p=0.001)$ and is significant than the indirect effect, which is also significant $(\mathrm{E}=0.073, p=0.004)$, thereby confirming partial mediation of procedural justice between HRP and stress in public-sector banks as shown in Table 5. Hence, hypothesis 4(b) is accepted.

Table 5: Procedural Justice as a Mediator between HRP and Stress in Private and public- Sector Banks

\begin{tabular}{lclllll}
\hline & Private Banks & & & Public Banks & Remarks \\
\hline \multicolumn{1}{c}{ Effect } & $\begin{array}{c}\text { Standardized } \\
\text { Beta }\end{array}$ & P value & Remarks & $\begin{array}{c}\text { Standardized } \\
\text { Beta }\end{array}$ & P value & \\
\hline Total Effect & 0.265 & 0.001 & No & .350 & .001 & Partial \\
Indirect Effect & 0.025 & 0.064 & Mediation & .073 & .004 & Mediation \\
Direct Effect & 0.240 & 0.001 & exists & .350 & .001 & exists \\
\hline
\end{tabular}

\section{Interactional Justice as a Mediator in Private and Public-Sector Banks}

H5 Interactional justice perception of HR practices mediates between HR practices and Job satisfaction in private (H5a) and Public (H5b)-sector banks.

Mediation analysis in private banks indicates that HRP (IV) significantly predicts interactional justice (DV) $(\beta=$ $0.33, \mathrm{p}=0.000)$, interactional justice also significantly predicts job satisfaction $(\beta=0.51, \mathrm{p}=0.000)$, and $\mathrm{HR}$ practices significantly predict job satisfaction $(\beta=0.32, p=.000)$. The direct effect $\left(r^{2}=0.14\right)$ of HR practices on job satisfaction gets increased to 0.31 (indirect) when procedural justice is introduced as a mediator. Further, bootstrapping results showed that direct effect is greater $(E=0.226, p=0.001)$ than the indirect effect, which is also significant $(E=0.117, p=0.000)$, thereby confirming partial mediation of interactional justice between HRP and job satisfaction in private-sector banks as shown in Table 6. Hence, hypothesis 5(a) is accepted.

Results in public-sector banks indicated that HRP(IV) significantly predicts interactional justice (DV) $(\beta=0.38, p$ $=0.000)$, interactional justice significantly predicts job satisfaction $(\beta=0.51, p=0.000)$, and HR practices significantly predict job satisfaction $(\beta=0.17, p=0.027)$. The direct effect $\left(r^{2}=0.14\right)$ of HR practices on job satisfaction increased to 0.36 when interactional justice is introduced as a mediator. Further, bootstrapping results as shown in Table 6, revealed that direct effect is less $(\mathrm{E}=0.179, p=0.030)$ than the indirect effect, which is not significant $(\mathrm{E}=0.204, p=0.001)$, thereby confirming partial mediation of interactional justice between HRP and job satisfaction in public sector banks. Hence, hypothesis 5(b) is accepted. 
Table 6: Interactional Justice as a Mediator Between HRP and Job Satisfaction in Private and PublicSector Banks

\begin{tabular}{rcclllll}
\hline \multicolumn{1}{c}{ Effect } & $\begin{array}{c}\text { Private Banks } \\
\end{array}$ & $\begin{array}{c}\text { Standardized } \\
\text { Beta }\end{array}$ & P value & Remarks & $\begin{array}{c}\text { Standardized } \\
\text { Beta }\end{array}$ & P value & \\
\hline Total Effect & 0.343 & 0.001 & Partial & 0.383 & .001 & Partial \\
Indirect Effect & 0.117 & 0.001 & Mediation & .204 & .001 & Mediation \\
Direct Effect & 0.226 & 0.001 & exists & .179 & .030 & exists \\
\hline
\end{tabular}

H6(b) Interactional justice perception mediates between HR practices and Stress in private (H6a) and Public (H6b) sector banks.

Results in Private Banks indicate that HR P (IV) significantly predicts interactional justice (DV) $(\beta=0.33, p$ $=.000)$, interactional justice also significantly predicts stress $(\beta=0.20, p=0.026)$, and HR practices significantly predicts stress $(\beta=.24, p=0.008)$. The direct effect $\left(r^{2}=0.09\right)$ of HR practices on stress gets increased to 0.13 when interactional justice is introduced as a mediator. Further, it was revealed through bootstrapping that an indirect effect $(\mathrm{E}=0.057, p=.018)$, was significant, thereby confirming mediation. Direct effect $(\mathrm{E}=0.208, p=$ 0.015 ) further shows significant results, thereby confirming partial mediation of interactional justice between HR practices and stress in private-sector banks as shown in Table 7. Hence, hypothesis 6(a) is accepted.

Results in Public-Sector Banks indicate that HRP(IV) significantly predicts interactional justice (DV) $(\beta=0.38, p$ $=0.000)$, interactional justice also significantly predicts stress $(\beta=0.20, p=0.025)$, and HRP significantly predicts stress $(\beta=0.23, p=0.010)$. The direct effect $\left(r^{2}=0.09\right)$ of HR practices on stress increased to 0.13 when interactional justice is introduced as a mediator. Further, bootstrapping results compared the effects and showed that the direct effect is higher $(\mathrm{E}=0.261, p=0.013)$ than the indirect effect, and is significant $(\mathrm{E}=0.089, p=$ 0.022), thereby confirming partial mediation of interactional justice between HRP and stress in public-sector banks (Table 7). Hence, hypothesis 6(b) is accepted.

Table 7: Interactional justice perception mediates between HR practices and Stress in private (H6a) and Public (H6b) sector banks.

\begin{tabular}{lcclllll}
\hline \multicolumn{1}{c}{ Effect } & Private Banks & $\begin{array}{c}\text { Standardized } \\
\text { Beta }\end{array}$ & P value & Remarks & $\begin{array}{c}\text { Standardized } \\
\text { Beta }\end{array}$ & P value & Remarks \\
\hline Total Effect & 0.266 & 0.001 & Partial & .350 & .001 & Partial \\
Indirect Effect & 0.208 & 0.015 & Mediation & .089 & .022 & Mediation \\
Direct Effect & 0.057 & 0.018 & exists & .261 & .013 & exists \\
\hline
\end{tabular}

To evaluate the final condition for mediation, we compared the reported values of coefficient of determination $\left(r^{2}\right)$ that can be used to compare the relative influence of mediating variables used. The framework which supports that higher value of $r^{2}$ is an indicator of better explanatory power of the independent variable in a regression model (Foster, Smith, \& Whaley, 1997). Since the research is conducted with the primary objective of proposing causal relationships among proposed variables, lower values of $r^{2}$ close to 50 percent were considered as suggested by Moksony (1990). Based on the results of hypothesis testing of mediated paths as presented in the above tables, the 
values of $r^{2}$ is mentioned collectively in table no. 8 .

Table 8: Relative Influence of Mediating Variables Through $\mathbf{r}^{2}$ Values

\begin{tabular}{|c|c|c|c|c|c|c|c|}
\hline \multirow[t]{2}{*}{ Hypothesis } & \multicolumn{3}{|c|}{ Path } & \multicolumn{2}{|c|}{ Private-sector banks } & \multicolumn{2}{|c|}{ Public-sector banks } \\
\hline & IV & MV & DV & $\begin{array}{c}r^{2} \\
\text { (indirect) }\end{array}$ & Remarks & $\begin{array}{c}r 2 \\
\text { (indirect) }\end{array}$ & Remarks \\
\hline H1 & HRP & DJ & Stress & 0.14 & $\begin{array}{l}\text { Partial } \\
\text { Mediation }\end{array}$ & 0.13 & Partial Mediation \\
\hline $\mathrm{H} 2$ & HRP & DJ & Sat & 0.39 & $\begin{array}{l}\text { Partial } \\
\text { Mediation }\end{array}$ & 0.32 & Partial Mediation \\
\hline H3 & HRP & PJ & Sat & 0.31 & $\begin{array}{l}\text { Partial } \\
\text { Mediation }\end{array}$ & 0.22 & Partial Mediation \\
\hline $\mathrm{H} 4$ & HRP & PJ & Stress & 0.12 & No Mediation & 0.16 & Partial Mediation \\
\hline H5 & HRP & IJ & Sat & 0.47 & $\begin{array}{l}\text { Partial } \\
\text { Mediation }\end{array}$ & 0.36 & Partial Mediation \\
\hline H6 & HRP & IJ & Stress & 0.13 & $\begin{array}{c}\text { Partial } \\
\text { Mediation }\end{array}$ & 0.13 & Partial Mediation \\
\hline
\end{tabular}

\section{CONCLUSIONAND DISCUSSION}

In an effort to understand and explore the prevalence of HR practices and "why" they give rise to positive and negative employee outcomes of job satisfaction and stress. The current study took recourse to the theory of organizational justice. The result shows that organizational justice varies in public-sector and private-sector banks. The results have a strong bearing on employee outcomes in the public-sector and private-sector banks and show The results of the study though showed that all justice dimensions, (viz: distributive justice, procedural justice and interactional justice) were important predictors of employee outcomes (stress and job satisfaction) but interactional justice was the most important predictor that determines job satisfaction in both private and public sector banks. The following section discusses the results of the path analysis separately for all justice dimensions.

Path analysis result reveals that distributive justice mediates between HR practices and employee outcomes of stress and job satisfaction in both private-sector and public-sector banks. Findings are consistent with previous literature in case of public-sector banks (Ghosh et al., 2014; Hackman \& Oldham, 1975) and implies that employee's distributive justice (in) in terms of allocation decisions pertaining to bonus, incentives, resources etc. leads to stress and job satisfaction, indicating employee's preference for equity (Chen, 1995). The results reported in this study suggest that banking organizations do plan their HR practices and invest accordingly in employees, thereby raising concern of fairness leading to stress. The results also supported the partial mediation of procedural justice between HR practices and job satisfaction which is consistent with the findings of Tang and Sarsfield- 
Baldwin (1996) that showed that an active inclusion of employees in the decision-making process facilitates a higher degree of job satisfaction. Procedural justice mediates partially between HR practices-stress relationship at public-sector banks but in the case of private-sector banks (H6a), stress is completely dependent on HR practices and is independent of the process of fairness. This indicates that employees reported higher stress in private-sector banks, which may be due to role overload and responsibility, in spite of having a high number of HR practices within their organizations. Studies have shown that there are other factors that influence stress at workplace; these factors can be listed as external competition, availability of resources, levels of control, and targets (Sargent \& Terry, 2000). There is a possibility that despite offering best HR practices in private-sector banks, stressors still exist in the working environment. These results are in line with the findings of the study conducted by Mostafa (2016), which explicitly states that HR practices can help in reducing stress of the employees by making sincere attempts at lessening role responsibility and role ambiguity. However, there is a very restricted support for this, and further study is required before any conclusions can be drawn. On the other hand, results show that employees of public-sector banks reported a high level of support from HR and thus, experienced lesser disruptions in the working environment, and support in terms of fairness of processes in reducing the stress level. This may be due to the fact the public-sector banks have well-defined process of recruitments, compensation, career growth, grievances, and promotions which helps in reducing the stress level (Grover \& Crooker, 1995).

Results supported partial mediation of interactional justice between organizational level HR practices and employee outcomes of job satisfaction and stress in both public-sector and private-sector banks. This gives an evidence that fair and impartial interactions by the supervisor during the implementation of any HR practice lead to the development of a social bond through social exchange process which results in both positive and negative employee reactions. In public-sector banks, results are consistent with these findings and employees vehemently voiced their opinion that interactional justice is a critical variable that controls exit behaviours of the employees; however, job satisfaction and stress can be controlled directly through HR Practices and do not pose an immediate threat. The result implies that when managers while implementing HR Practices show sensitivity and concern toward an employee, his reactions can be controlled, which is consistent with Levinson (1965) findings, who argued that a manager serves as a microcosm of the organization for an employee. This confirms and solidifies that two-way interaction between outcome and process is important (Skarlicki \& Folger,1997).

\section{IMPLICATIONS}

The findings from this study would help the HR practitioners within banking industry by acknowledging the importance of HR practices that can impact employee outcomes. Banking organizations may use these insights of this research to design HR practices that can be regarded as just and fair. These findings challenge the investment made by HR practitioners in terms of trainings, manpower, incentives, new courses etc. while implementing the HR processes as employees in the banking industry do not give due weightage to them. However, they are more concerned about the interactional justice in terms of information shared and interactions made by the leader. Therefore, interactional justice brought by a leader is a pathway that may help organizations achieve their goals. This suggests that the leader who is responsible for interacting and sharing the information plays a much stronger role in ensuring positive employee outcomes.

These findings also have important theoretical implications and adds additional support to the organizational justice theory. The study provides a framework for future research by trying to explain "how" HR practices relate to different employee outcome at an individual level. The results extend the research in HRM and OB literature and also offers support to the work of Takeuchi et al., (2009) by evaluating employee outcomes at an individual level. 
Although the study has contributed extensively to the theory, practice, and methodology part ,but the study has few limitations that would play a monumental role in shaping future research on the subject. Since this study was conducted using cross-sectional research design, it was difficult to test the causal relationships and their directions. Thus, it can be construed as one of the limitations, which can be effectively resolved by adopting a longitudinal research design. Second limitation is about the measurement of scales of organizational justice perceptions. Organizational justice scale has been built keeping in close consideration to studies conducted in the west. As a result there could be a possibility that the indigenous attributes and contextual reality of Indian banks might have been omitted.. Therefore, the future studies should consider conducting a longitudinal study by considering the limitations of the study.

\section{REFERENCES}

Adams, J. S. (1965). Inequity in social exchange. In Advances in experimental social psychology (Vol. 2, pp. 267299). New York: Academic Press.

Asadullah, M. A., Akram, A., Imran, H., \& Arain, G. A. (2017). When and which employees feel obliged: a personality perspective of how organizational identification develops. Revista de Psicología del Trabajo yde las Organizaciones, 33(2), 125-135.

Becker, B., \& Gerhart, B. (1996). The impact of human resource management on organizational performance: Progress and prospects. Academy of management journal, 39(4), 779-801.

Beer, M., Spector, B. A., Lawrence, P. R., Mills, D. Q., \& Walton, R. E. (1984). Managing human assets. Simon and Schuster.

Bies, R. J. (2001). Interactional (injustice: The sacred and the profane. In J. Greenberg \& R. Cropanzano (Eds.), Advances in organizational justice (pp. 89-118).

Bies, R. J., \& Moag, I. S. 1986. Interactional justice: communication criteria of fairness. In B. H. a. B.Steppard, M. H. (Ed.), Research on Negotiation in Organizations, Vol. 1:43-55.

Boselie, P., Brewster, C., \& Paauwe, J. (2009). In search of balance-managing the dualities of HRM: an overview of the issues. Personnel Review, 38(5), 461-471.

Bowen, D. E., Gilliland, S. W., \& Folger, R. (1999). HRM and service fairness: How being fair with employees spills over to customers. Organizational Dynamics, 27(3), 7-23.

Cartwright, S., \& Cooper, C. L. (1993). The psychological impact of merger and acquisition on the individual: A study of building society managers. Human relations, 46(3), 327-347.

Chen, C. C. (1995). New trends in rewards allocation preferences: A Sino-US comparison. Academy of Management journal, 38(2), 408-428.

Colley, L., McCourt, W., \& Waterhouse, J. (2012). Hybrids and contradictions: Human resource management in the contemporary public sector. International Journal of Public Administration, 35(8), 507-512.

Collins, C. J., Ericksen, J., \& Allen, M. (2005). Employee outcomes: human resource management practices and firm performance in small businesses. CAHRS Working Paper Series, 485.

Colquitt, J. A. (2001). On the dimensionality of organizational justice: A construct validation of a measure. Journal of applied psychology, 86(3), 386.

Colquitt, J.A., Conlon, D. E., Wesson, M. J., Porter, C. O., \& Ng., K. Y. (2001). Justice at the millennium: A metaanalytic review of 25 years of organizational justice research. Journal of Applied Psychology, 86, 425-445.

Colquitt, J. A., \& Greenberg, J. 2003. Organizational justice: A fair assessment of the state of the literature. In J.Greenberg(Ed.), Organizational behavior: The state of the science: 165-210. Mahwah, NJ: Erlbaum.

Conway, E., Fu, N., Monks, K., Alfes, K., \& Bailey, C. (2016). Demands or resources? The relationship between HR practices, employee engagement, and emotional exhaustion within a hybrid model of employment relations. Human Resource Management, 55(5), 901-917.

Coyle-Shapiro, J., \& Kessler, I. (2000). Consequences of the psychological contract for the employment 
relationship: Alarge scale survey. Journal of management studies, 37(7), 903-930.

Dainty, A R J, Bagilhole, B M and Neale, R H (1998) Improving the retention of construction professionals: a soft HRM approach. In: Hughes, W (Ed.), 14th Annual ARCOM Conference, 9-11 September 1998, University of Reading. Association of Researchers in Construction Management, Vol. 1, (pp. 9-11).

Delbridge, R., \& Lowe, J. (1997). Managing human resources for business success: a review of the issues. International Journal of Human Resource Management, 8(6), 857-873.

Delery, J. E. (1998). Issues of fit in strategic human resource management: Implications for research. Human resource management review, 8(3), 289-309.

Denis, J. L., Ferlie, E., \& Van Gestel, N. (2013). Public Management Reforms and the Growth of Hybridity. European Group for Organizational Studies (EGOS), Montreal.

Devonish, D. (2013). Workplace bullying, employee performance and behaviors: The mediating role of psychological well-being. Employee Relations, 35(6), 630-647.

Dyer, L., \& Reeves, T. (1995). Human resource strategies and firm performance: what do we know and where do we need to go?. International Journal of human resource management, 6(3), 656-670.

Eatough, E. M., Chang, C. H., Miloslavic, S. A., \& Johnson, R. E. (2011). Relationships of role stressors with organizational citizenship behavior: a meta-analysis. Journal of Applied Psychology, 96(3), 619.

Ehrnrooth, M., \& Björkman, I. (2012). An integrative HRM process theorization: Beyond signalling effects and mutual gains. Journal of Management Studies, 49(6), 1109-1135.

Farndale, E., Van Ruiten, J., Kelliher, C., \& Hope-Hailey, V. (2011). The influence of perceived employee voice on organizational commitment: An exchange perspective. Human Resource Management, 50(1), 113-129.

Fernandes, C., \& Awamleh, R. (2006). Impact of organisational justice in an expatriate work environment. Management researchnews, 29(11), 701-712.

Folger, R., \& Konovsky, M. A. (1989). Effects of procedural and distributive justice on reactions to pay raise decisions. Academy of Managementjournal, 32(1), 115-130.

Folger, R., \& Cropanzano, R. (1998). Organizational justice and human resource management (Vol.7). Thousand Oaks, CA: Sage.

Folger, R., \& Cropanzano, R. (2001). Fairness theory: Justice as accountability. Advances in organizational justice, 1, 1-55.

Fombrun, C. J., Tichy, N. M., \& Devanna, M. A. (1984). Strategic HRM. NY: Wiley.

Fornell, C., \& Larcker, D. F. (1981). Structural equation models with unobservable variables and measurement error: Algebra and statistics. Journal of marketing research, 382-388.

Foster, F. D., Smith, T., \& Whaley, R. E. (1997). Assessing goodness-of-fit of asset pricing models: The distribution of the maximal R2. The Journal of Finance, 52(2), 591-607.

Ghosh, P., Rai,A., \& Sinha, A. (2014). Organizational justice and employee engagement: Exploring the linkage in public sector banks in India. Personnel Review, 43(4), 628-652.

Gilliland, S. W., \& Chan, D. (2001). Methods, and Applications. Handbook of Industrial, Work \& Organizational Psychology: Volume 2: Organizational Psychology, 143.

Greenberg, J. (1993). The Intellectual Adolescence of Organizational Justice: You've Come A Long Way, Maybe. Social Justice Research, 6(1), 135-148.

Grover, S. L., \& Crooker, K. J. (1995). Who Appreciates Family-Responsive Human Resource Policies: The Impact Of Family-Friendly Policies On The Organizational Attachment of Parents And Non-Parents. Personnel Psychology, 48(2), 271-288.

Guest, D. (1987). Human resource management and industrial relations. Journal of Management Studies, 24(5), pp. 503-521.

Guest, D. E. (2017). Human Resource Management and Employee Well-Being: Towards A New Analytic Framework. Human Resource Management Journal, 27(1), 22-38.

Guthrie, James P. 2001. "High-Involvement Work Practices, Turnover, and Productivity: Evidence from New 
Zealand." Academy of Management Journal, 44(1):180-90.

Gould-Williams, J. (2007). HR practices, organizational climate and employee outcomes: evaluating social exchange relationships in local government. The International Journal of Human Resource Management, 18(9), 1627-1647.

Gould-Williams, J., \& Mohamed, R. B. (2010). A comparative study of the effects of 'best practice'HRM on worker outcomes in Malaysia and England local government. The International Journal of Human Resource Management, 21(5), 653-675.

Judge, T. A., \& Klinger, R. (2008). Job satisfaction. The science of subjective well-being, 393.

Hackman, J. R., \& Oldham, G. R. (1975). Development Of The Job Diagnostic Survey. Journal Of Applied Psychology, 60(2), 159.

Harley, B., Allen, B.C. and Sargent, L.D. (2007), "High performance work systems and employee experience of work in the service sector: the case of aged care", British Journal of Industrial Relations, 45(3), 607-633.

Hayibor, S. (2017). Is fair treatment enough? Augmenting the fairness-based perspective on stakeholder behaviour. Journal of Business Ethics, 140(1), 43-64.

Heffernan, M., \& Dundon, T. (2016). Cross-level effects of high-performance work systems (HPWS) and employee well-being: the mediating effect of organisational justice. Human Resource Management Journal, 26(2), 211-231.

Huong, L., Zheng, C., \& Fujimoto, Y. (2016). Inclusion, organisational justice and employee well-being. International Journal of Manpower, 37(6), 945-964.

Huselid, M. A. (1995). The impact of human resource management practices on turnover, productivity, and corporate financial performance. Academy of management journal, 38(3), 635-672.

Jiang, K., Lepak, D. P., Hu, J., \& Baer, J. C. (2012). How Does Human Resource Management Influence Organizational Outcomes? A Meta-Analytic Investigation of Mediating Mechanisms. Academy of Management Journal, 55(6), 1264-1294.

Kaneshiro, P. (2008). Analyzing the Organizational Justice, Trust, And Commitment Relationship In A Public Organization. Doctoral Dissertation, Northcentral University, USA.

Karunakaran, K. P. (2018). Religion and political awakening in India. Meenakshi Prakashan(1965).

Katou, A. A., Budhwar, P. S., \& Patel, C. (2014). Content vs. process in the HRM-performance relationship: An empirical examination. Human Resource Management, 53(4), 527-544.

Khoreva, V., \& Wechtler, H. (2018). HR Practices and Employee Performance: The Mediating Role of WellBeing. Employee Relations, 40(2), 227-243.

Krishnan, L. (2015). Social exclusion, mental health, disadvantage and injustice. Psychology and developing societies, 27(2), 155-173.

Kundu, S. C., \& Gahlawat, N. (2015). Socially responsible HR practices and employees' intention to quit: The mediating role of job satisfaction. Human Resource Development International, 18(4), 387-406.

Kuvaas, B. (2008). An exploration of how the employee-organization relationship affects the linkage between perception of developmental human resource practices and employee outcomes. Journal of Management Studies, 45(1), 1-25.

Legge, K. 1995. Human resource management: Rhetorics and realities. Basingstoke, UK: Palgrave Macmillan.

Leventhal, G. S. (1980). What should be done with equity theory? New approaches to the study of fairness in social relationships. In K. Gergen, M. Greenberg, \& R. Willis (Eds.), Social exchange: Advances in theory and research (pp. 27-55). New York: Plenum.

Levinson, H. (1965). Reciprocation: The relationship between man and organization. Administrative science quarterly, 370-390.

Liao, H., Toya, K., Lepak, D. P., \& Hong, Y. (2009). Do they see eye to eye? Management and employee perspectives of high-performance work systems and influence processes on service quality. Journal of applied psychology, 94(2), 371. 
MacDuffie, J. P. (1995). Human resource bundles and manufacturing performance: Organizational logic and flexible production systems in the world auto industry. ILR Review, 48(2), 197-221.

Macky, K., \& Boxall, P. (2007). The relationship between 'high-performance work practices' and employee attitudes: an investigation of additive and interaction effects. The International Journal of Human Resource Management, 18(4), 537-567.

Mathieu, J. E., \& Farr, J. L. (1991). Further evidence for the discriminant validity of measures of organizational commitment, job involvement, and job satisfaction. Journal of Applied Psychology, 76(1), 127.

Mallinckrodt, B., Abraham, W. T., Wei, M., \& Russell, D. W. (2006). Advances in testing the statistical significance of mediation effects. Journal of Counseling Psychology, 53(3), 372.

McFarlin, D. B., \& Sweeney, P. D. (1992). Distributive and procedural justice as predictors of satisfaction with personal and organizational outcomes. Academy of management Journal, 35(3), 626-637.

Mischel, W., \& Shoda, Y.(1995). A cognitive-affective system theory of personality: reconceptualizing situations, dispositions, dynamics, and invariance in personality structure. Psychological review, 102(2), 246.

Moksony, F. (1990). Small is beautiful. The use and interpretation of R2 in social research. Szociológiai Szemle, Special issue, 130-138.

Mostafa, A. M. S. (2016). High-performance HR practices, work stress and quit intentions in the public health sector: Does person-organization fit matter?. Public Management Review, 18(8), 1218-1237.

Nidhi, and Kumari,k. (2019). A Confirmatory Factor Analysis of pay satisfaction dimensions in Banking Industry, Ramanunjan International Journal of Business and Research, 4(1), 269-290.

Noon, M. (1992). HRM: A Map, Model or Theory? [in:] P. Blyton, P. Turnbull (eds.), Reassessing Human Resource Management. London: Sage, 16-32.

Noypayak, W., \& Speece, M. (1998). Tactics to influence subordinates among Thai managers. Journal of Managerial Psychology.13(5), 343-358.

Preacher, K. J., \& Hayes, A. F. (2004). SPSS And SAS Procedures For Estimating Indirect Effects In Simple Mediation Models. Behavior Research Methods, Instruments, \& Computers, 36(4), 717-731.

Sanders, K., \& Yang, H. (2016). The HRM process approach: The influence of employees' attribution to explain the HRM-performance relationship. Human Resource Management, 55(2), 201-217.

Shain, M. (1999). Workplace Culture: Stress And Satisfaction. Occupational Health And Safety. Canada, 15, 3847.

Sharma,E., \& Sindhu,J. (2016). A study to measure the relationship between the Performance and it's Indicators in commercial Banks. Ramanunjan International Journal of Business and Research, 1(1), 177-193.

Skarlicki, D. P., \& Folger, R. (1997). Retaliation in The Workplace: The Roles Of Distributive, Procedural, And Interactional Justice. Journal of Applied Psychology, 82(3), 434.

Sparrow, P. R. (1998). Reappraising psychological contracting: Lessons for the field of human-resource development from cross-cultural and occupational psychology research. International Studies of Management \& Organization, 28(1), 30-63.

Takeuchi, R., Chen, G., \& Lepak, D. P. (2009). Through The Looking Glass Of A Social System: Cross-Level Effects Of High-Performance Work Systems On Employees' Attitudes. Personnel Psychology, 62(1), 1-29.

Tang, T. L.-P., \& Sarsfield-Baldwin, L. J. (1996). Distributive and procedural justice as related to satisfaction and commitment. SAMAdvanced Management Journal, 61, 25-31.

Truss, C. (2013). The distinctiveness of human resource management in the public sector. In Human resource management in the public sector. Edward Elgar Publishing.

Wood, S., \& De Menezes, L. M. (2011). High involvement management, high-performance work systems and well-being. The International Journal of Human Resource Management, 22(07), 1586-1610. 